\title{
EFFECT OF BIOGEIN, RHIZOBACTERIEN AND VIVA ROSE FERTILIZATION ON GROWTH AND CHEMICAL COMPOSITION OF Cupressus sempervirens, L. SEEDLINGS.
}

HANAN M. A. YOUSSEF and HESHAM A. GHARIB

Floriculture and Landscape Design and Woody Trees Res. Dep., Hort. Res. Ins., ARC, Giza, Egypt.

(Manuscript received 18 March 2013)

\begin{abstract}
In this study, seedlings one year old of Cupressus sempervirens, planted in the nursery of Woody Trees Res. Dept., Hort. Res. Inst., Giza, Egypt. For two successive years (2011 and 2012) to investigate the best bio-fertilization treatments and the suitable doses on growth of Cupressus by "Biogein or Rhizobacterien at the rates of 2.50, 5.00 and $7.50 \mathrm{~g} / \mathrm{bag}$ as well as chemical fertilizer with "Viva Rose" as a foliar spray at the rates of $1.00,2.00 \& 4.00 \mathrm{~g} / \mathrm{l}$.Seedlings were grown in $14 \mathrm{~cm}$ diameter black polyethylene bag filled with a mixture of sand plus loam (1:1, $\mathrm{v}$. $/ \mathrm{v}$.) were used in this investigation. Results indicated that plant height and stem diameter, showed a significant increased by adding Biogien at the rate $2.50 \mathrm{~g} / \mathrm{bag}$, compared to control. Spraying the seedlings with "Viva Rose" at the rate of 4.00ppm induced utmost means of number of branches and leaves /plant, compared with the control and other treatments. While untreated plants gave the longest of root length /plant. Combination treatment "Biogein plus Rhizobacterien at the rate 2.50 plus $1.00 \mathrm{ppm}$ "Viva Rose" recorded high increases of fresh and dry weights of aerial parts "stem and leaves". However, fresh and dry weights of roots were increased significantly by addition Biogien at the rate of $5.00 \mathrm{~g} / \mathrm{bag}$ and $1.00 \mathrm{ppm}$ of "Viva Rose". Chemical compositions were highly variance in response to all fertilizer treatments compared with the untreated plants. Biogien at the rate of $2.50 \mathrm{~g} / \mathrm{bag}$ level increased significantly chlorophyll $\mathrm{a}$, total chlorophyll" a +b", N\% and nutrient uptake. Meanwhile, Rhizobacterien at the rate of $2.50 \mathrm{~g} / \mathrm{bag}$ elevated contents of leaves from chlorophyll b, carotenoids, and total indoles. Total phenols increased by "Viva Rose" at the rate of $4.00 \mathrm{ppm}$, but spraying "Viva Rose" at the rate of $2.00 \mathrm{ppm}$ increased P\%. While, P, K \% were highly increased at the rate of $5.00 \mathrm{~g} / \mathrm{bag}$ Rhizobacterien.

From the obtained results it could be recommended, that the addition of Biogien at $2.5 \mathrm{~g} /$ bags to Cupressus sempervirens seedlings (grown in $14 \mathrm{~cm}$ diameter bags thrice with one month interval from "March to May" during the growing season) resulted in the best and strong seedlings, besides to short the time in nursery in order to realization the coast of seedlings producing and to save our environment.

Keywords: Bio-fertilizer, "Biogein- Rhizobacterien", Foliar Fertilization, "Viva Rose", Vegetative growth, Chemical composition, Cupressus sempervirens.
\end{abstract}




\section{INTRODUCTION}

Italian Cypress Tree -Cupressus sempervirens, L. family Cupressaceae is also sometimes known as the Mediterranean Cypress or the Tuscan Cypress. No other tree epitomises the Tuscan landscape as this tall, narrow coniferous tree. Its pencil shape is often used in Italian garden design and in formal gardens around the world. Cupressus sempervirens is a beautiful evergreen upright conifer that is easy to grow in the UK climate, it is hardy and tolerates all conditions, both as a specimen tree in its own right or if a group are grown alongside each other it makes for an extremely effective, yet very elegant evergreen screen.The vast majority of the trees in cultivation are selected cultivars with a fastigiate crown, with erect branches forming a narrow to very narrow crown often less than a tenth as wide as the tree is tall. The dark green 'exclamation mark' shape of these trees is a highly characteristic signature of Mediterranean towns and village landscapes. Formerly, the species was sometimes separated into two varieties, the wild $C$. sempervirens var. sempervirens (syn. var. horizontalis), and the fastigiate C. s. var. pyramidalis (syn. var. fastigiata, var. stricta), but the latter is now only distinguished as a Cultivar Group, with no botanical significance. It is also known for its very durable, scented wood, used most famously for the doors of St. Peter's Basilica in the Vatican City, Rome. Cypress used to be used in distilleries as staves to hold mash ferments to make alcohol before the invention of stainless steel. Commonly seen throughout New Mexico, the Mediterranean Cypress is also known as the "drama tree" because of its tendency to bend with even the slightest of breezes. In cosmetics, it is used an astringent, firming, antiseborrheic, antidandruff, antiaging and as fragance, according to Bailey (1976) and Carrasco (2009). Subba Rao (1993) affirmed that Azotobacter chroococcum "which is found in Biogein fertilizer" synthesize antifungal antibiotics that gives it a special advantage for use in field production. El-Sayed et al.,(2007) on Ficus binnendijkii, L. 'Amstel King' plants indicated that, using Biogien at the rate of $10 \mathrm{~g} /$ plant improve all plant characteristics studied (plant height, stem diameter, number of leaves and branches/plant, fresh and dry weights of leaves, stems and roots, and chlorophyll $a, b$ and carotenoids content, and $\mathrm{N}, \mathrm{P}$ and $\mathrm{K}$ percentages of the leaves). Moreover, treating the plants with Biogien at the rate of $5 \mathrm{~g} /$ plant or rizobacterene at the rate of $10 \mathrm{~g} /$ plant revealed also great influence on plant parameters in both seasons. AbdelFattah et al., (2009a) indicated that (bio-fertilizer as a soil drench at the rate of 10 $\mathrm{ml} / /$ plus spraying it at the rate of $5 \mathrm{ml} / \mathrm{l}$.) significantly improved all vegetative and root growth parameters, of Dracaena marginata "Bicolor" Lam. and Ruscus hypoglossum . 
So this investigation aims to limit the best type and suitable dose of some biofertilizer "Biogien or Rizobacterien" or "Viva Rose" as a foliar spray to realize the high quality of Cupressus sempervirens seedlings growth.

\section{MATERIALS AND METHODS}

This investigation was carried out on Woody Trees nursery of the Experimental Farm of Hort. Res. Inst., Giza, Egypt during 2011 and 2012 years, to study the effect of bio-fertilizer "Biogien or Rizobacterien" or chemical-fertilizer "Viva Rose" as a foliar sprays at various rates on growth and chemical composition of Cupressus sempervirens. One year-old seedlings of Cupressus were transplants with height initial of 10-12 cm and carrying 8-10 leaves were planted in both seasons, individually in black polyethylene bags of $14 \mathrm{~cm}$ diameter filled with equal mixture sand and loam (1:1 v: v).

The physical and chemical properties of the used mixture soil are shown in Table (a) which, was analyzed according to Champan and Pratt (1978).

Table a. Physical and chemical properties of the used mixture medium in the two years (2011and 2012).

\begin{tabular}{|c|c|c|c|c|c|c|c|c|c|c|c|c|c|c|c|}
\hline \multirow{2}{*}{ Season } & \multicolumn{8}{|c|}{ Particles size distribution (\%) } & \multirow{2}{*}{\multicolumn{2}{|c|}{$\begin{array}{c}\text { E.C. } \\
(\mathrm{dS} / \mathrm{m})\end{array}$}} & \multirow{2}{*}{$\mathrm{pH}$} & \multicolumn{4}{|c|}{ Cations (meq/L) } \\
\hline & $\begin{array}{c}\text { Coarse } \\
\text { sand }\end{array}$ & $\begin{array}{l}\text { Fine } \\
\text { sand }\end{array}$ & Silt & Clay & \multicolumn{2}{|c|}{$\begin{array}{c}\text { Organic } \\
\text { matter }\end{array}$} & \multicolumn{2}{|c|}{$\mathrm{CaCO}_{3}$} & & & & $\mathrm{Ca}^{++}$ & $\mathrm{Mg}^{++}$ & $\mathrm{Na}^{+}$ & $\mathrm{K}^{+}$ \\
\hline 2011 & 15.2 & 25.5 & 18.4 & 36.4 & 1. & & & & 2.9 & & 7.58 & 7.55 & 2.34 & 10.90 & 0.75 \\
\hline \multirow[t]{3}{*}{2012} & 15.3 & 24.7 & 17.8 & 38.0 & 1. & & & & 2.7 & & 7.50 & 10.33 & 1.56 & 8.67 & 0.75 \\
\hline & \multicolumn{4}{|c|}{ Anions (meq/L) } & \multicolumn{11}{|c|}{ Macro-and micro-elements (ppm) } \\
\hline & $\mathrm{HCO}_{3}^{-}$ & $\mathrm{Cl}^{-}$ & \multicolumn{2}{|c|}{$\mathrm{SO}_{4}^{--}$} & $\mathrm{N}$ & & $P$ & & & & e & $\mathrm{Zn}$ & \multicolumn{2}{|c|}{$\mathrm{Mn}$} & $\mathrm{Cu}$ \\
\hline 2011 & 3.94 & 8.64 & \multicolumn{2}{|c|}{8.96} & 164.20 & & .01 & \multicolumn{2}{|c|}{370.50} & \multicolumn{2}{|c|}{12.00} & 3.70 & \multicolumn{2}{|c|}{7.62} & 8.76 \\
\hline 2012 & 4.08 & 7.96 & \multicolumn{2}{|c|}{9.27} & 173.16 & & .78 & \multicolumn{2}{|c|}{361.76} & \multicolumn{2}{|c|}{15.80} & 4.36 & \multicolumn{2}{|c|}{8.03} & 8.80 \\
\hline
\end{tabular}

After a month from planting "on $20^{\text {th }}$ of March", the seedlings received monthly the following treatments three times for both seasons:

1-No fertilization, referred to as control.

2-Biofertilizer with either Biogien (a commercial product that contains a specific clone of Azotobacter chroococcum bacteria, conc. $10^{6} \mathrm{cell} / \mathrm{s} / \mathrm{ml}$ ) and Rhizobacterien (a Commercial product containing a specific strain of Rhizobium sp. bacteria, conc. $10^{7}-10^{8}$ cells $/ \mathrm{m}$ ) at the rates of $2.50,5.00$ and $7.50 \mathrm{~g} /$ seedling.

3-Liquid fertilizer (Table (b) clear the content's of "Viva Rose" fertilizer according to the production company "UAD" Union for Agric. Development w/w. was sprayed on the foliage till run-off, point at the levels of $1.00,2.00$ and $4.00 \mathrm{~g} / \mathrm{l}$. of water. 
4- A combination of Biogien a t 2.5g/seedling + Rhizobacterien at $2.5 \mathrm{~g} /$ seedling+Viva

Rose at $1.00 \mathrm{~g} / \mathrm{l}$.

Table b. The content's of "Viva Rose" fertilizer:

\begin{tabular}{|c|c|c|c|c|c|c|c|c|c|l|}
\hline $\mathrm{N} \%$ & $\begin{array}{c}\mathrm{P} \% \\
\mathrm{"} \mathrm{P}_{2} \mathrm{O}_{5} "\end{array}$ & $\begin{array}{c}\mathrm{K} \% \\
" \mathrm{~K}_{2} \mathrm{O} "\end{array}$ & $\mathrm{Fe} \%$ & $\mathrm{Zn} \%$ & $\mathrm{Mn} \%$ & $\mathrm{Cu} \%$ & $\mathrm{Mg} \%$ & $\mathrm{Ml} \%$ & $\begin{array}{c}\text { Citric } \\
\text { acid\% }\end{array}$ & sucrose\% \\
\hline 22.00 & 5.00 & 11.00 & 0.05 & 0.07 & 0.24 & 0.05 & 0.3 & 0.5 & 0.002 & 0.07 \\
\hline
\end{tabular}

-All plants under the various treatments received the usual agricultural practices such as weeding ....etc. whenever needed.

\section{- Data were taken at the end of each year (on $8^{\text {th }}$ September) as follows:}

Plant height $(\mathrm{cm}$.$) , stem diameter (\mathrm{cm}$.$) , number of branches/plant, number of$ leaves/plant, length of roots/plant (cm.), as well as, fresh and dry weights of aerial parts" stems and leaves" and fresh and dry weights of roots $(\mathrm{g})$.

- Meanwhile, in fresh leaf samples they were taken from the middle parts of the plants, photosynthetic pigments (chlorophyll a, b and carotenoids, mg/g F.W.) were determined according to Moran, R. (1982).

- In fresh leaf the total indoles and total soluble phenols were determined colourimetrically by using Folin Ciocaltea reagent A.O.A.C. (1990).

-While in dry aerial parts, the percentages of nitrogen was determined using microKjeldahle method as described by Jackson (1973), phosphorus, was measured colorimetrically as indicated by Cottenie et al., (1982) in addition to potassium using a Flamephotometer set as reported by Jackson (1973). Nutrient uptake (g/plant) Jackson,(1973) were calculated by using formula as follows.

Nutrient uptake $(\mathrm{g} /$ plant $)=$ Nutrient content $(\%) *$ dry matter $(\mathrm{g}) / 100$

The layout of the experiment in the two seasons was a randomized complete block design (RCBD) with three replicates (Mead et al., 1993), as each replicate consisted of nine plants.

-Data were then tabulated and subjected to analysis of variance according to SPSS Program (Levesque, 2007) using Duncan's Multiple Range Test (1955) was used to verify the significance level among means of various treatments.

\section{RESULTS AND DISCUSSION}

Table (1) show that plant height was significantly increased by plants fertilized with Biogien at the rate of $2.5 \mathrm{~g} / \mathrm{bag}$ or sprayed with "Viva Rose" at the rate $2.00 \mathrm{ppm}$ and untreated plant compared to other treatments in the first season whereas the utmost means were recorded in the second year by addition Biogien at the rate of $2.5 \mathrm{~g} / \mathrm{bag}$. Meanwhile stem diameter significantly increased by using Biogien at the rate of $2.5 \mathrm{~g} / \mathrm{bag}$. Number of branches /plant and number of leaves /plant recorded much increases by Viva Rose fertilizer at the rate of $4.00 \mathrm{ppm}$ in the two year. The 
control gave the highest mean of root length /plant comparing to all other treatments. Results of growth parameters were in agreement with those obtained by Abdel-Fattah et al (2009) on Dracaena marginata and Ruscus hypoglossum.

Table (2) It is clear that the treating plants with Biogien at the rate of 5.00 $\mathrm{g} / \mathrm{bag}$, "Viva Rose" at the rate of 4.00ppm and Biogien plus Rhizobacterien at the rate of $2.5 \mathrm{~g} / \mathrm{bag}$ plus" Viva Rose" at the rate of $1.00 \mathrm{ppm}$ gave highly values of fresh and dry weights of aerial parts. On the other hand, fresh and dry roots were increased by plants treated with Biogien bio-fertilizer at the rate of $5 \mathrm{~g} / \mathrm{bag}$ or "Viva Rose "at the rate of $1.00 \mathrm{ppm}$ treatments which were insignificant for the two seasons under study. Rhizobacterien recorded less water amount between fresh and dry weights. This may be attributed to the capability of Biogein in fixing more atmospheric $\mathrm{N}$ and secrete more vitamins and growth promoting substances necessary for good and healthy growth Subba Rao,(1993) reported the same on Azotobacter chroococcum .On the same line were those results of Abdel-Fattah et al (2009) on Dracaena and Ruscus.

Table 1. Effect of Biogein, Rhizobacterien and "Viva Rose" treatments on some vegetative growth parameters of Cupressus sempervirens seedling during 2011 and 2012 years.

\begin{tabular}{|c|c|c|c|c|c|}
\hline \multirow[t]{2}{*}{ Treatments } & $\begin{array}{l}\text { Plant height } \\
\quad(\mathrm{cm})\end{array}$ & $\begin{array}{c}\text { Stem } \\
\text { diameter } \\
(\mathrm{cm}) \\
\end{array}$ & $\begin{array}{c}\text { No. of } \\
\text { Branches/ } \\
\text { plant }\end{array}$ & $\begin{array}{l}\text { No. of } \\
\text { Leaves/ } \\
\text { plant }\end{array}$ & $\begin{array}{l}\text { Root length / } \\
\text { plant } \\
(\mathrm{cm}) \\
\end{array}$ \\
\hline & \multicolumn{5}{|c|}{ First year : 2011} \\
\hline Control & $25.67 \mathrm{~A}$ & $0.31 \mathrm{AB}$ & $0.67 \mathrm{C}$ & $23.34 \mathrm{BC}$ & $12.67 \mathrm{~A}$ \\
\hline Biogien at $2.5 \mathrm{~g} / \mathrm{bag}$ & $25.67 \mathrm{~A}$ & $0.34 \mathrm{~A}$ & $0.00 \mathrm{C}$ & 21.00B-D & $11.34 \mathrm{AB}$ \\
\hline Biogien at $5 \mathrm{~g} / \mathrm{bag}$ & $19.00 \mathrm{AB}$ & $0.27 A B$ & $0.00 \mathrm{C}$ & 21.34B-D & 9.34D-F \\
\hline Biogien at $7.5 \mathrm{~g} / \mathrm{bag}$ & $21.67 A B$ & $0.27 \mathrm{AB}$ & $0.00 \mathrm{C}$ & 20.67B-D & $9.67 \mathrm{C}-\mathrm{F}$ \\
\hline Rhizobacterien at $2.5 \mathrm{~g} / \mathrm{bag}$ & $19.00 \mathrm{AB}$ & $0.31 \mathrm{AB}$ & $0.00 \mathrm{C}$ & 14.67D & $9.51 \mathrm{D}-\mathrm{F}$ \\
\hline Rhizobacterien at $5 \mathrm{~g} / \mathrm{bag}$ & $21.34 \mathrm{AB}$ & $0.24 A B$ & $0.00 \mathrm{C}$ & $16.67 C D$ & $8.67 \mathrm{~F}$ \\
\hline Rhizobacterien at $7.5 \mathrm{~g} / \mathrm{bag}$ & $22.67 \mathrm{AB}$ & $0.21 \mathrm{AB}$ & $0.00 \mathrm{C}$ & 19.00B-D & $11.00 \mathrm{BC}$ \\
\hline Viva Rose at $1.00 \mathrm{ppm}$ & $17.34 \mathrm{~B}$ & $0.24 \mathrm{AB}$ & $0.00 \mathrm{C}$ & $14.00 \mathrm{D}$ & 10.34B-E \\
\hline Viva Rose at 2.00ppm & $25.34 \mathrm{~A}$ & $0.27 A B$ & $0.00 \mathrm{C}$ & $18.00 \mathrm{CD}$ & $9.00 \mathrm{EF}$ \\
\hline Viva Rose at 4.00ppm & $19.34 \mathrm{AB}$ & $0.24 \mathrm{AB}$ & $4.67 \mathrm{~A}$ & $44.67 \mathrm{~A}$ & $11.67 \mathrm{AB}$ \\
\hline \multirow[t]{2}{*}{$\begin{array}{l}\text { Biogien + Rhizobacterien at } \\
2.5 \mathrm{~g} / \mathrm{bag}+\text { Viva } \\
\text { at1.00ppm }\end{array}$} & $19.00 \mathrm{AB}$ & $0.17 \mathrm{~B}$ & $3.67 \mathrm{~B}$ & $26.67 \mathrm{~B}$ & 10.67B-D \\
\hline & \multicolumn{5}{|c|}{ Second year :2012 } \\
\hline Control & $25.00 \mathrm{AB}$ & $0.24 \mathrm{~A}$ & $1.00 \mathrm{C}$ & $23.00 \mathrm{BC}$ & $12.00 \mathrm{~A}$ \\
\hline Biogien at $2.5 \mathrm{~g} / \mathrm{bag}$ & $27.34 \mathrm{~A}$ & $0.37 \mathrm{~A}$ & $0.00 \mathrm{D}$ & $19.67 \mathrm{BC}$ & $10.67 \mathrm{~A}-\mathrm{C}$ \\
\hline Biogien at $5 \mathrm{~g} / \mathrm{bag}$ & $23.00 \mathrm{~A}-\mathrm{C}$ & $0.31 \mathrm{~A}$ & $0.00 \mathrm{D}$ & $20.67 \mathrm{BC}$ & $9.00 \mathrm{CD}$ \\
\hline Biogien at $7.5 \mathrm{~g} / \mathrm{bag}$ & 20.00B-D & $0.37 \mathrm{~A}$ & $0.00 \mathrm{D}$ & $19.34 \mathrm{BC}$ & 9.34B-D \\
\hline Rhizobacterien at $2.5 \mathrm{~g} / \mathrm{bag}$ & 21.00B-D & $0.37 \mathrm{~A}$ & $0.00 \mathrm{D}$ & $14.00 \mathrm{BC}$ & $9.00 \mathrm{CD}$ \\
\hline Rhizobacterien at 5g/bag & $22.00 \mathrm{~A}-\mathrm{D}$ & $0.31 \mathrm{~A}$ & $0.00 \mathrm{D}$ & $16.00 \mathrm{BC}$ & $8.00 \mathrm{D}$ \\
\hline Rhizobacterien at $7.5 \mathrm{~g} / \mathrm{bag}$ & 20.00B-D & $0.37 \mathrm{~A}$ & $0.00 \mathrm{D}$ & $18.67 \mathrm{BC}$ & $10.67 \mathrm{~A}-\mathrm{C}$ \\
\hline Viva Rose at 1.00ppm & $17.00 \mathrm{D}$ & $0.34 \mathrm{~A}$ & $0.00 \mathrm{D}$ & $12.67 \mathrm{C}$ & $10.00 \mathrm{BC}$ \\
\hline Viva Rose at 2.00ppm & $25.67 \mathrm{AB}$ & $0.37 \mathrm{~A}$ & $0.00 \mathrm{D}$ & $17.00 \mathrm{BC}$ & $8.00 \mathrm{D}$ \\
\hline Viva Rose at 4.00ppm & $18.67 \mathrm{CD}$ & $0.27 \mathrm{~A}$ & $4.34 \mathrm{~A}$ & $41.34 \mathrm{~A}$ & $11.00 \mathrm{AB}$ \\
\hline $\begin{array}{l}\text { Biogien + Rhizobacterien at } \\
2.5 \mathrm{~g} / \mathrm{bag}+\text { Viva } \\
\text { Roseat1.00ppm }\end{array}$ & 20.00B-D & $0.27 \mathrm{~A}$ & $3.00 \mathrm{~B}$ & $26.34 \mathrm{~B}$ & 9.67B-D \\
\hline
\end{tabular}


Table 2. Effect of Biogein, Rhizobacterien and "Viva Rose" treatments on fresh and dry weights of different parts of Cupressus sempervirens seedling during 2011 and 2012 years.

\begin{tabular}{|c|c|c|c|c|}
\hline \multirow[t]{2}{*}{ Treatments } & $\begin{array}{c}\text { Fresh weight of } \\
\text { Aerial parts } \\
\text { (g) }\end{array}$ & $\begin{array}{l}\text { Dry weight of } \\
\text { Aerial parts } \\
\text { (g) }\end{array}$ & $\begin{array}{l}\text { Fresh weight of } \\
\text { Roots } \\
\text { (g) }\end{array}$ & $\begin{array}{l}\text { Dry weight of } \\
\text { Roots }(\mathrm{g})\end{array}$ \\
\hline & \multicolumn{4}{|c|}{ First year : 2011} \\
\hline Control & $3.98 \mathrm{~A}$ & $2.67 A B$ & $0.78 \mathrm{~A}$ & $0.41 \mathrm{~A}$ \\
\hline Biogien at $2.5 \mathrm{~g} / \mathrm{bag}$ & $3.72 \mathrm{~A}$ & $2.48 \mathrm{~B}-\mathrm{E}$ & $0.67 \mathrm{~A}$ & $0.36 \mathrm{~A}$ \\
\hline Biogien at $5 \mathrm{~g} / \mathrm{bag}$ & $4.46 \mathrm{~A}$ & $2.86 \mathrm{AB}$ & $1.04 \mathrm{~A}$ & $0.45 \mathrm{~A}$ \\
\hline Biogien at $7.5 \mathrm{~g} / \mathrm{bag}$ & $3.43 \mathrm{~A}$ & $2.56 \mathrm{~B}-\mathrm{D}$ & $0.57 \mathrm{~A}$ & $0.31 \mathrm{~A}$ \\
\hline Rhizobacterien at $2.5 \mathrm{~g} / \mathrm{bag}$ & $3.15 \mathrm{~A}$ & $2.49 \mathrm{~B}-\mathrm{E}$ & $0.54 \mathrm{~A}$ & $0.29 \mathrm{~A}$ \\
\hline Rhizobacterien at $5 \mathrm{~g} / \mathrm{bag}$ & $2.69 \mathrm{~A}$ & $2.14 \mathrm{E}-\mathrm{G}$ & $0.62 \mathrm{~A}$ & $0.22 \mathrm{~A}$ \\
\hline Rhizobacterien at $7.5 \mathrm{~g} / \mathrm{bag}$ & $2.86 \mathrm{~A}$ & $2.28 \mathrm{C}-\mathrm{F}$ & $0.54 \mathrm{~A}$ & $0.34 \mathrm{~A}$ \\
\hline Viva Rose at 1.00ppm & $2.77 \mathrm{~A}$ & $1.76 \mathrm{G}$ & $0.63 \mathrm{~A}$ & $0.31 \mathrm{~A}$ \\
\hline Viva Rose at 2.00ppm & $2.91 \mathrm{~A}$ & 2.19D-F & $0.64 \mathrm{~A}$ & $0.41 \mathrm{~A}$ \\
\hline Viva Rose at 4.00ppm & $5.19 \mathrm{~A}$ & $2.97 \mathrm{~A}$ & $0.38 \mathrm{~A}$ & $0.29 \mathrm{~A}$ \\
\hline \multirow[t]{2}{*}{$\begin{array}{l}\text { Biogien + Rhizobacterien at } \\
2.5 \mathrm{~g} / \mathrm{bag}+\text { Viva Rose at1.00ppm }\end{array}$} & $3.19 \mathrm{~A}$ & $2.15 \mathrm{E}-\mathrm{G}$ & $0.38 \mathrm{~A}$ & $0.21 \mathrm{~A}$ \\
\hline & \multicolumn{4}{|c|}{ Second year :2012 } \\
\hline Control & $3.74 \mathrm{AB}$ & $2.34 \mathrm{AB}$ & $0.64 \mathrm{~A}$ & $0.34 \mathrm{~A}$ \\
\hline Biogien at $2.5 \mathrm{~g} / \mathrm{bag}$ & $3.34 \mathrm{AB}$ & $2.00 \mathrm{AB}$ & $0.74 \mathrm{~A}$ & $0.31 \mathrm{~A}$ \\
\hline Biogien at $5 \mathrm{~g} / \mathrm{bag}$ & $2.67 \mathrm{AB}$ & $2.67 \mathrm{~A}$ & $0.74 \mathrm{~A}$ & $0.44 \mathrm{~A}$ \\
\hline Biogien at $7.5 \mathrm{~g} / \mathrm{bag}$ & $3.00 \mathrm{AB}$ & $2.00 \mathrm{AB}$ & $0.54 \mathrm{~A}$ & $0.27 \mathrm{~A}$ \\
\hline Rhizobacterien at $2.5 \mathrm{~g} / \mathrm{bag}$ & $3.00 \mathrm{AB}$ & $2.00 \mathrm{AB}$ & $0.51 \mathrm{~A}$ & $0.21 \mathrm{~A}$ \\
\hline Rhizobacterien at $5 \mathrm{~g} / \mathrm{bag}$ & $2.34 \mathrm{~B}$ & $2.00 \mathrm{AB}$ & $0.57 \mathrm{~A}$ & $0.21 \mathrm{~A}$ \\
\hline Rhizobacterien at $7.5 \mathrm{~g} / \mathrm{bag}$ & $2.34 \mathrm{~B}$ & $2.00 \mathrm{AB}$ & $0.47 \mathrm{~A}$ & $0.31 \mathrm{~A}$ \\
\hline Viva Rose at $1.00 \mathrm{ppm}$ & $2.34 \mathrm{~B}$ & $1.67 \mathrm{~B}$ & $0.57 \mathrm{~A}$ & $0.27 \mathrm{~A}$ \\
\hline Viva Rose at 2.00ppm & $3.67 \mathrm{AB}$ & $2.00 \mathrm{AB}$ & $0.61 \mathrm{~A}$ & $0.37 \mathrm{~A}$ \\
\hline Viva Rose at 4.00ppm & $5.00 \mathrm{~A}$ & $2.67 \mathrm{~A}$ & $0.34 \mathrm{~A}$ & $0.27 \mathrm{~A}$ \\
\hline $\begin{array}{l}\text { Biogien + Rhizobacterien at } \\
2.5 \mathrm{~g} / \mathrm{bag}+\text { Viva Rose at1.00ppm }\end{array}$ & $3.00 \mathrm{~B}$ & $1.67 \mathrm{~B}$ & $0.31 \mathrm{~A}$ & $0.14 \mathrm{~A}$ \\
\hline
\end{tabular}

Means within a column having the same letters are not significantly different according to Duncan's Multiple Range Test at 5\% level.

\section{Chemical composition:}

Data in Table (3) and "Fig. 1 and 2" showed a significant increased in chlorophyll a, b and carotenoids contents in leaves by using bio-fertilizer with Biogien or Rhizobacterien and "Viva Rose" fertilization. Treating plants with Biogien the rate of $2.5 \mathrm{~g} / \mathrm{bag}$ raised the means of chlorophyll a $(2.67 \mathrm{mg} / \mathrm{g})$ over the control means 1.37 mg/g F.W. and total chlorophyll "a + b". Meanwhile, Rhizobacterien at the rate of 2.5 $\mathrm{g} /$ bag significantly increased chlorophyll $b$, carotenoids and total indole contents in leaves of cupressus seedlings.

Total phenols, showed a highly increased by "Viva Rose" at the rate of $4.00 \mathrm{ppm}$. The percentage of $\mathrm{N}, \mathrm{P}$ and $\mathrm{K}$ were markedly increased due to the different treatments of fertilization, the highest significant percentage from $\mathrm{N}$ induced by addition Biogien at the rate of $2.50 \mathrm{~g} / \mathrm{bag}$ and Rhizobacterien at the rate of $5.00 \mathrm{~g} / \mathrm{bag}$ .Spraying plants with "Viva Rose" at 2.00ppm recorded high amount of P\%. While, $\mathrm{K}$ percentage significantly increased by Rhizobacterien at the rate of $5.00 \mathrm{~g} / \mathrm{bag}$ treatment compared to its untreated plant or all the other treatments. However, 
Biogien at the rate of $2.50 \mathrm{~g} / \mathrm{bag}$ recorded significantly increased of nutrient uptake contents in leaves.

These results due to the role of $\mathrm{N}$ in chlorophylls and amino acids synthesis, and $\mathrm{P}$ which contributes in regulating the opening and closing of stomata and possibly membrane turgor that affect chlorophyll formation through its radioactive properties. Phosphorus would activate various metabolic processes and it is involved in energy transfer process during building of phospholipids and nucleic acids Marschner, (1995). Moreover, $\mathrm{P}$ provides plant metabolic process with phosphate bonds, which are necessary for building pigments and other constituents Baek, et al (1999).

Table 3. Effect of Biogein, Rhizobacterien and "Viva Rose" treatments on chemical composition of Cupressus sempervirens seedling during 2012 year.

\begin{tabular}{|c|c|c|c|c|c|c|c|c|}
\hline Treatments & $\begin{array}{l}\text { Chloroph } \\
\text { yll (a) } \\
\text { (mg/g } \\
\text { f.w.) }\end{array}$ & $\begin{array}{l}\text { Chloroph } \\
\text { yll (b) } \\
\text { (mg/g } \\
\text { f.w.) }\end{array}$ & $\begin{array}{l}\text { Carotenoi } \\
\text { ds } \\
\text { (mg/g } \\
\text { f.w.) }\end{array}$ & $\begin{array}{l}\text { Total } \\
\text { indoles } \\
(\mathrm{mg} / \mathrm{g} \\
\text { f.w.) }\end{array}$ & $\begin{array}{c}\text { Total } \\
\text { phenols } \\
\text { (mg/g } \\
\text { f.w.) }\end{array}$ & $\mathrm{N} \%$ & P\% & $\mathrm{K} \%$ \\
\hline Control & $1.37 \mathrm{~B}$ & $0.48 \mathrm{C}$ & $0.75 \mathrm{~A}$ & $0.02 \mathrm{~B}$ & $0.02 \mathrm{I}$ & $0.42 \mathrm{D}$ & $2.69 \mathrm{C}$ & $1.01 \mathrm{~F}$ \\
\hline Biogien at $2.5 \mathrm{~g} / \mathrm{bag}$ & $2.67 \mathrm{~A}$ & $0.13 \mathrm{E}$ & $0.26 \mathrm{C}$ & $0.04 \mathrm{~B}$ & $0.02 \mathrm{I}$ & $0.70 \mathrm{~B}$ & $0.34 \mathrm{I}$ & $\begin{array}{c}1.44 \\
B\end{array}$ \\
\hline Biogien at $5 \mathrm{~g} / \mathrm{bag}$ & $0.28 \mathrm{~F}$ & $0.26 \mathrm{D}$ & $0.63 A B$ & $0.08 \mathrm{~B}$ & $0.02 \mathrm{I}$ & $0.84 \mathrm{~A}$ & $0.20 \mathrm{~J}$ & $\begin{array}{c}1.24 \\
D \\
\end{array}$ \\
\hline Biogien at $7.5 \mathrm{~g} / \mathrm{bag}$ & $0.27 \mathrm{~F}$ & $0.15 \mathrm{E}$ & $0.32 \mathrm{C}$ & $0.31 \mathrm{~A}$ & $0.08 \mathrm{G}$ & $0.42 \mathrm{D}$ & $\begin{array}{c}0.81 \\
\mathrm{G}\end{array}$ & $1.12 \mathrm{E}$ \\
\hline $\begin{array}{l}\text { Rhizobacterien at } 2.5 \\
\mathrm{~g} / \mathrm{bag}\end{array}$ & $0.41 \mathrm{D}$ & $1.65 \mathrm{~A}$ & $0.75 \mathrm{~A}$ & $0.32 \mathrm{~A}$ & $0.09 \mathrm{~F}$ & $0.84 \mathrm{~A}$ & $2.31 \mathrm{E}$ & $\begin{array}{l}1.55 \\
A B\end{array}$ \\
\hline $\begin{array}{l}\text { Rhizobacterien at } \\
5 \mathrm{~g} / \mathrm{bag}\end{array}$ & $0.18 \mathrm{G}$ & $0.15 \mathrm{E}$ & $0.62 A B$ & $0.02 B$ & $0.10 \mathrm{E}$ & $0.56 \mathrm{C}$ & $\begin{array}{c}0.47 \\
\mathrm{H} \\
\end{array}$ & $\begin{array}{c}1.61 \\
\mathrm{~A} \\
\end{array}$ \\
\hline $\begin{array}{l}\text { Rhizobacterien at } 7.5 \\
\mathrm{~g} / \mathrm{bag}\end{array}$ & $0.59 \mathrm{C}$ & $0.12 \mathrm{E}$ & $0.45 B C$ & $0.02 B$ & $0.13 \mathrm{D}$ & $056 \mathrm{C}$ & $3.95 \mathrm{~B}$ & $\begin{array}{c}1.49 \\
B \\
\end{array}$ \\
\hline Viva Rose at $1.00 \mathrm{ppm}$ & $0.61 \mathrm{H}$ & $0.17 \mathrm{E}$ & $0.16 \mathrm{C}$ & $0.02 B$ & $0.19 \mathrm{C}$ & $0.56 \mathrm{C}$ & $\begin{array}{c}3.02 \\
D \\
\end{array}$ & $\begin{array}{c}1.32 \\
\mathrm{C}\end{array}$ \\
\hline Viva Rose at 2.00ppm & $0.19 \mathrm{G}$ & $1.32 \mathrm{~B}$ & $0.35 \mathrm{BC}$ & $0.02 B$ & $0.18 \mathrm{C}$ & 042D & $4.95 \mathrm{~A}$ & $\begin{array}{c}1.21 \\
\mathrm{D} \\
\end{array}$ \\
\hline Viva Rose at 4.00ppm & $0.38 \mathrm{E}$ & $0.13 \mathrm{E}$ & $0.18 \mathrm{C}$ & $0.02 B$ & $0.32 \mathrm{~A}$ & $042 \mathrm{D}$ & $0.96 \mathrm{~F}$ & $1.15 \mathrm{E}$ \\
\hline $\begin{array}{l}\text { Biogien }+ \\
\text { Rhizobacterien at } \\
2.5 \mathrm{~g} / \text { bag +Viva Rose } \\
\text { at1.00ppm }\end{array}$ & $0.19 \mathrm{G}$ & $0.12 \mathrm{E}$ & $0.32 \mathrm{C}$ & $0.02 B$ & $0.21 \mathrm{~B}$ & 042D & $2.34 \mathrm{E}$ & $\begin{array}{c}1.22 \\
D\end{array}$ \\
\hline
\end{tabular}

Means within a column having the same letters are not significantly different according to Duncan's Multiple Range Test at $5 \%$ level. 


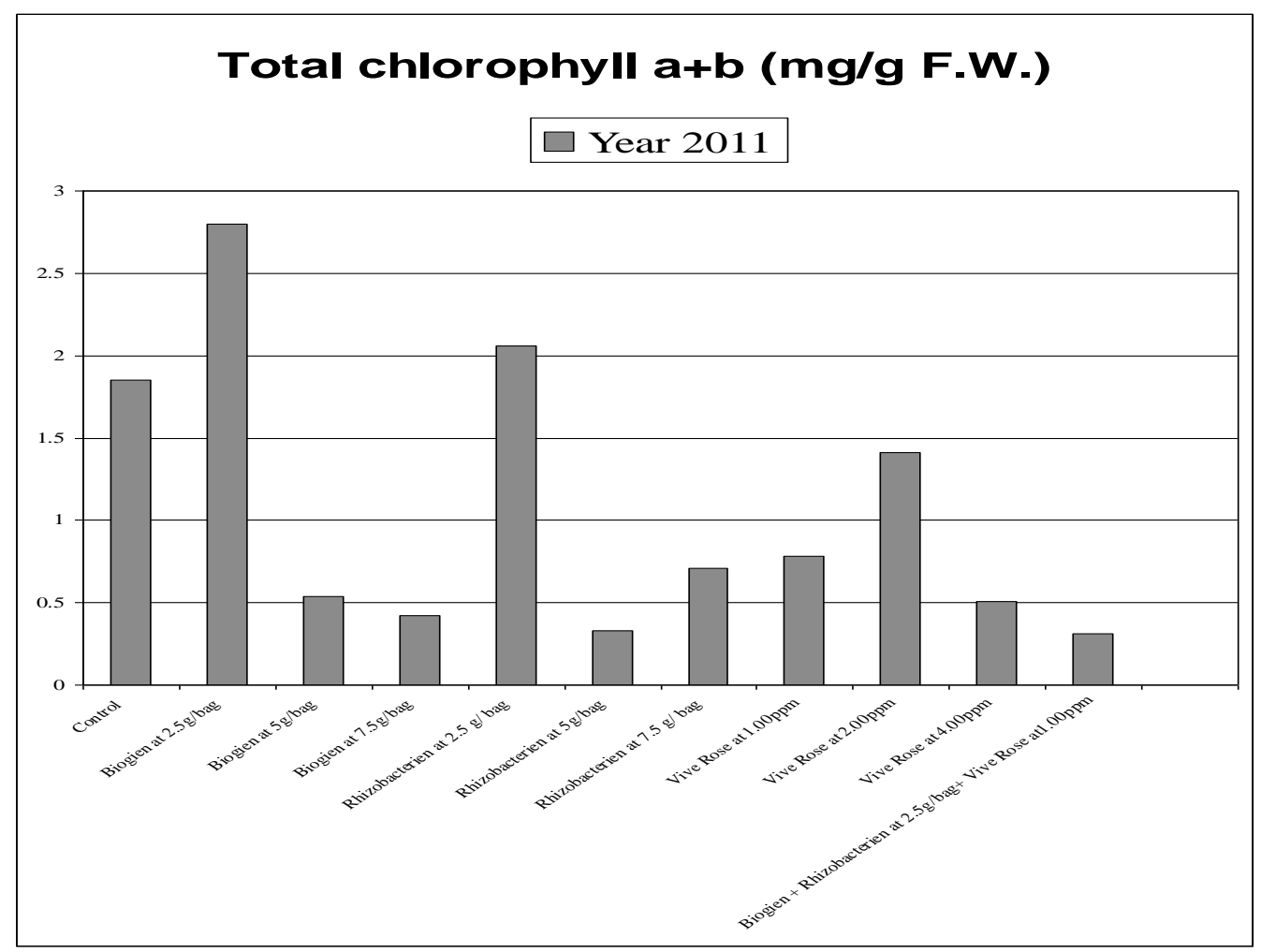

Figure 1. Histogram showing the effect of bio and chemical fertilization on total chlorophyll "a+b" (mg/g) of Cupressus sempervirens seedlings.

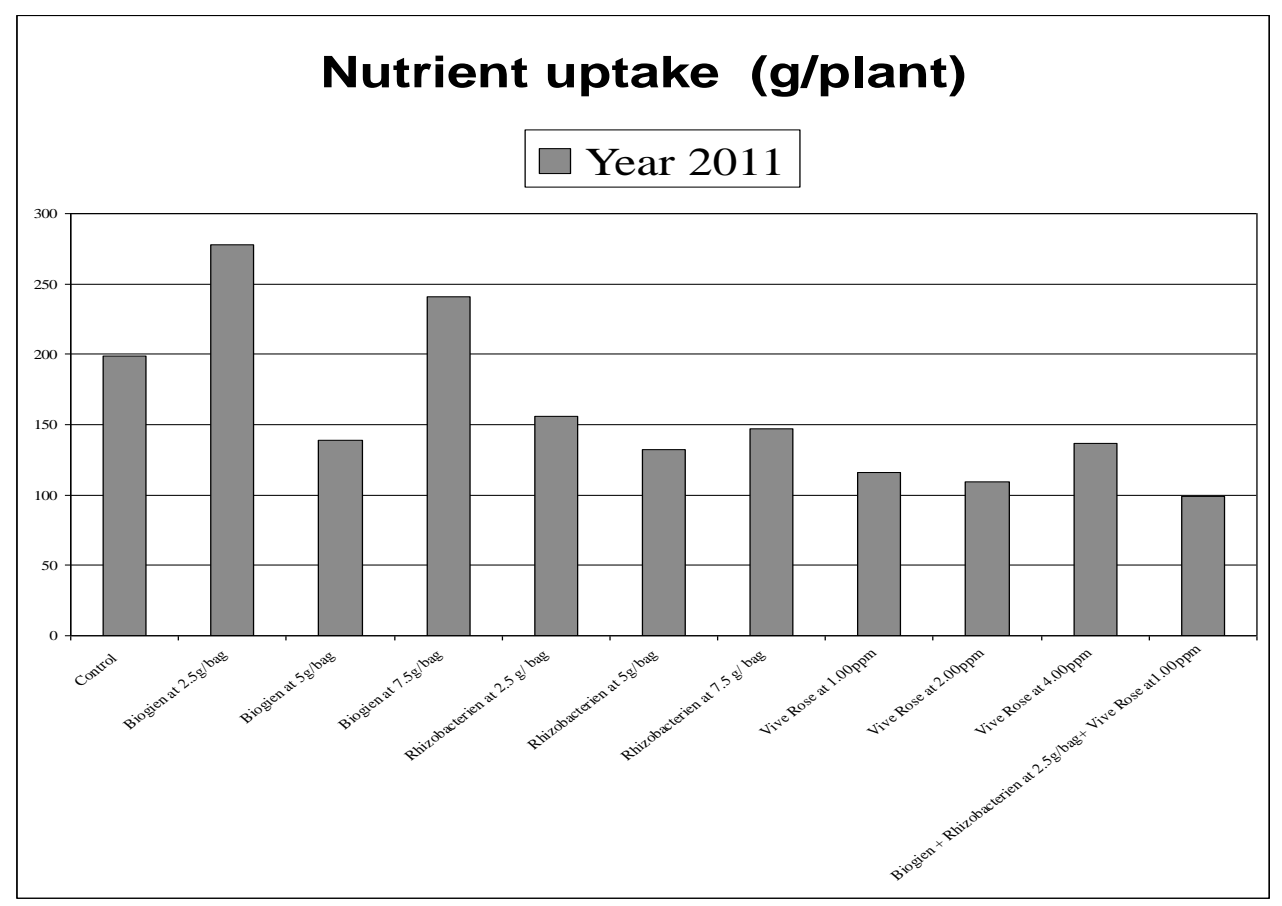

Figure 2. Histogram showing the effect of bio and chemical fertilization on nutrient uptake (g/plant) of Cupressus sempervirens seedlings. 


\section{REFERENCES}

1. Abdel-Fattah, Gehan H., A.El-Sayed, Boshra, and A. M. Khenizy, Soad. 2009a. Response of Dracaena and Ruscus plants to humic acid and bio-fertilizer supply. Annals of Agric. Sci., Moshtohor, Vol, 47(1):111-119.

2. A.O.A.C. 1990. Official Methods of Analysis ( $15^{\text {th }}$.ed) Association of Official Agricultural Chemists Washington. USA. Pp 62-63,236 and 877-878.

3. Baek, Y., C. Pack, M. Huh and B. Kwack. 1999. Effect of environmental factors on the defoliation and enzyme activity of Hibiscus syriacus L. J. Korean Soc. Hort. Sci., 40(2): 235-240.

4. Bailey, L.H. 1976. Hortus Third. Macmillan Publishing Co., Inc., 866 Third Avenue, New Yourk, N.Y. 100 22.1290pp.

5. Carrasco, F. 2009. "Ingredientes Cosméticos". Diccionario de Ingredientes\ $4^{\mathrm{a}}$ Ed. www. Imagenpersonal .net. p. 267 . ISBN 978-84- 613-4979-1.

6. Champan, H.D. and P.F. Pratt. 1978. Methods of analysis for soils, plants and water. P. 150 and 169 Univ. of California, Div. Agric. Sci., Priced pub. 4034 , USA.

7. Cottenie, A., M. Verloo, L. Kiekan, G. Velghe and R. Comerlynck. 1982. Chemical analysis of plants and Soils. Laboratory of Analytical and Agrochemistry. State Univ., Ghent-Belgium, P. 44-45.

8. Duncan, D.B. 1955. Multiple range and multiple F-tests. Biometrices, 11:1-42.

9. El -Sayed, Boshra A. and A.E.H. EI-Feky. 2007. Effect of Bio fertilizers (Rizobacterene, Nitrobiene and Biogein) on growth of Ficus binnendijkii ,L."Amstel king"plants. Egypt. J. of Appl. Sci., 22 (10A): 157 -170.

10. Jackson, M. L. 1973. Soil Chemical Analysis. Prentice - Hall of India Private Ltd. M-97,New Delhi, India, 498 pp.

11. Levesque, R. 2007. SPSS Programming and Data Management: A Guide for SPSS and SAS Users, Fourth Edition. 2007. SPSS Inc., Chicago Ill. PDF ISBN 1-56827390-8 SPSS 15.0 Command Syntax Reference 2006, SPSS Inc., Chicago IIl .

12. Marschner, H. 1995. Mineral Nutrition of Higher plants. $2^{\text {nd }}$ Ed., Academic Press, London. Pp. 99-101.

13. Mead, R., R.N. Curnow and A.M. Harted. 1993. Statistical Methods in Agriculture and Experimental Biology, $2^{\text {nd }}$ Ed., Chapman \& Hall Ltd., London, 335 pp.

14. Moran, R. 1982. Formula for determination of chlorophyllous pigment extracted with N-N-dimethyl formamide. Plant physiol., 69:1376-81.

15. Subba Rao,N.S. 1993. Bio fertilizers in Agriculture,3 ${ }^{\text {rd }}$ Ed., Oxford \&IBH Publishing Co. Ltd., New DeIhi,Bombay.Calcutta,242pp .

16. Thompson, B.E. 1985. Evaluating Seedling Quality: Principles, Rocedures and Predictive Abilities of Major Tests. Forest Research Laboratory, Oregon State Univ., Corvallis. pp 59-71. 


\section{تأثيرمعاملات التسميد بالبيوجين والريزويكترين والفيفا روز على النمو والتركيب الكيماوى لشتيلات السرو}

حنان محمد أحمد يوسف، هشام عبد السلام غريب

$$
\text { معهد بحوث البساتين، مركز البحوث الزبات الزينه وتنسيق الحدائق و قسم بحوث الأشجار الخشبيه الجيزة - مصر }
$$

أجري هذا البحث على شتلات السرو عمرسنه بمشتل قسم بحوث الأشجار الخشبيه - معهد

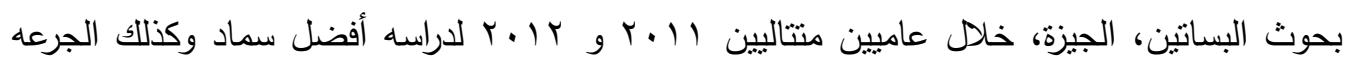

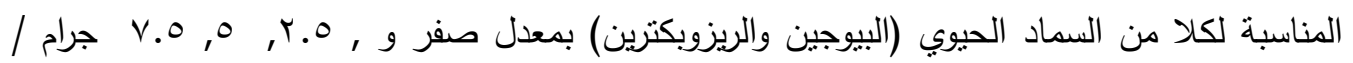

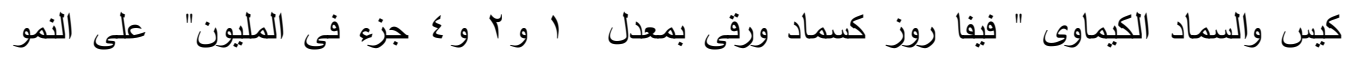

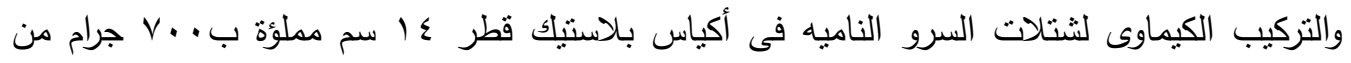

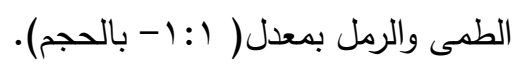

\section{وقد أوضحت النتائج المتحصل عليها على ما يلي:-}

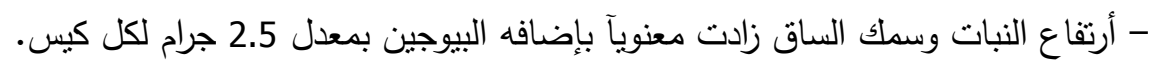

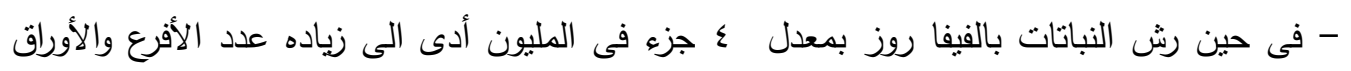

$$
\text { /نبات مقارنه بالكنترول والمعاملات الأخرى. }
$$

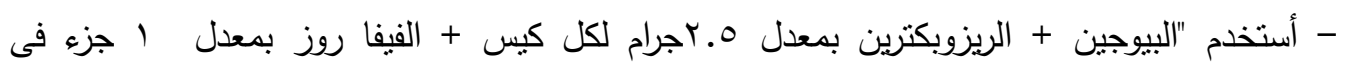

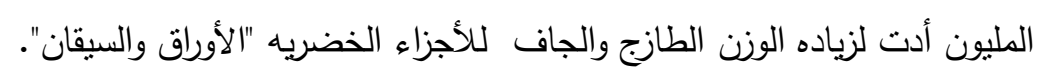

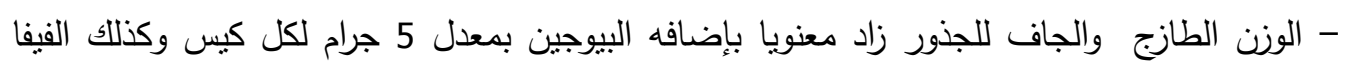

$$
\text { روز بمعدل ا جزء فى المليون. }
$$

-البيوجين بمعدل ه. ب جرام لكل كيس أدى لزياده كلوروفيل أ والكلورفيل الكلى والنسبه المئويه للنتروجين وكذلك النتروجين الممتص ـ النص

- الريزوبكترين بمعدل هـ ـجرام لكل كيس أدى لزياده محتوى الأوراق من كلوروفيل ب والكاروتينويدات و الآندولات الكليه.

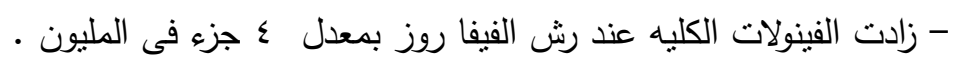
- الريزوبكترين بمعدله جرام /كبس أدى إلى زياده النسبه المئويه للبوتاسيوم.

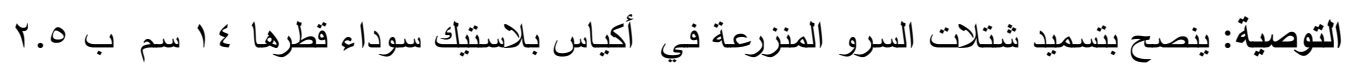

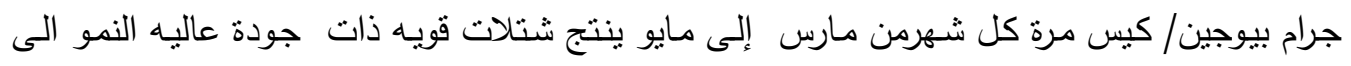

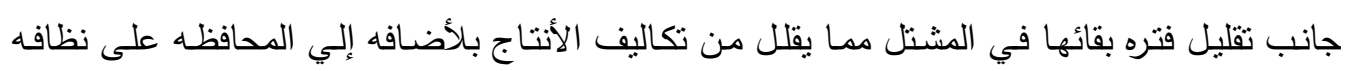

